Journal of Teacher Education for Sustainability, vol. 12, no. 1, pp. 66-74, 2010

\title{
SUSTAINABLE LEADERSHIP OF SENIOR STUDENTS: THE CASE STUDY OF MADEIRA
}

\author{
António Bento \\ University of Madeira (CIE-UMa), Portugal \\ Isabel Ribeiro \\ Mountain Research Centre - \\ Polytechnical Institute of Bragança, Portugal
}

\begin{abstract}
Secondary education plays a key role in developing sustainable leadership skills in students. This research analyses the characteristics of sustainable leadership of students at 2 secondary schools in Madeira Island (Portugal) in order to determine whether the type of school or gender of the students affect eight distinct domains: 1) self management; 2) interpersonal relations; 3) problem solving/decision making; 4) cognitive critical development/analysis; 5) organization and planning; 6) self-confidence; 7) diversity awareness; 8) technology. The Student Leadership Outcomes Inventory (SLOI) (Vann, 2000) was used to measure the leadership experiences of 158 senior students in these eight areas. Participants revealed moderate levels of sustainable leadership in the eight sub-scales. The findings show that students of Madeira Island who finish secondary education possess several well-developed sustainable leadership skills.
\end{abstract}

Key words: sustainable leadership, sustainable leadership skills, sustainable leadership abilities, competencies

\section{Introduction}

Students of secondary education have an opportunity to develop diverse sustainable leadership abilities during their schooling. Poom-Valickis and Elvisto (2009) state that "education is an essential tool for achieving sustainability" (p. 4). The concept of sustainability is related to the development and preservation of what it is important as well as individuals' ability to create positive connections among people. According to Hargreaves and Fink (2007), "the sustainable leadership focuses on three important questions: it preserves, protects and promotes a deep and large learning of all, based in relations of care with each other" (p. 39). The literature on the sustainable leadership abilities of students has largely focused on higher education because of the belief that developing these competencies is the responsibility of this level of education. However, one set of 
studies has focused on the capacities of secondary education students. This literature is clear about the importance of acquiring sustainable capacities at this educational level. As a result, there is a need to study in more depth the sustainable leadership capacities with which students arrive at the university and/or the labour market.

Employers report that they look for candidates who possess transversal abilities in several disciplines such as reading, writing, creative thought, personal organization, easy integration in working groups, organizational efficiency and leadership capacities (Kerka, 1990; Attinasi, 1992; Grogyer \& Eide, 1994; Aksoy \& Mittelhauser, 1998).

Employers also look for candidates who possess well-developed capacities of sustainable leadership (Linden \& Fertman, 1998; Gale, 2002; Santosus, 2003). Sustainable abilities developed in secondary education can be categorized as follows: a) technical competencies that reflect the specialized knowledge, tools and techniques that leaders possess and use (Stronge, 1998); b) conceptual competencies that are constituted by intelligence, decision making, capacity to see the whole and capacity to foresee change (Stronge, 1998) and c) human capacities which encompass the capacity to work with and for others (Stronge, 1998). Alternately, according to Kouzes and Posner (1995, 2009), the four main characteristics looked for by the employers are: 1) honesty to measure one's behaviour by high standards and to demonstrate the behaviour that one expects of others; 2) the capacity to inspire others to have a dream, a vision and a capacity of inspiring a joint vision; 3 ) the capacity to inspire others to act and participate in joint work as a true team; 4) the capacity to encourage the will, to awaken and maintain the will to achieve the delineated objectives (Kouzes \& Posner, 1995, 2009).

There is little congruence in the literature regarding the relationship between sustainable leadership capacities and gender. Some studies reveal little relationship between gender and sustainable leadership (Powell, 1989; Bass, 1991; Komives, 1991; Posner \& Brodsky, 1994). Others, however, conclude that leadership abilities are more developed in women, in particular the ability to inspire others to act was identified as very well developed in women, even those with little leadership experience (Komives, 1994). According to Romano (1996), women value interpersonal relationships more than men, learn more by trial and error and by observation and have more practice in acquiring leadership abilities, conflict resolution and problem solving.

\section{Methodology}

The objective of this research study was to analyse the sustainable characteristics and competencies of leadership of senior students in two schools of the Autonomous Region of Madeira (Portugal). A 60-item questionnaire developed by Vann (2000) classifies sustainable leadership capacities according to eight domains (see Table 1). Each item employs a 4 point Likert scale (1 - Completely disagree; 2 - Disagree; 3 - Agree; 4 Completely agree) asking subjects to indicate their level of agreement with a statement.

The first sub-scale consists of nine items and evaluates the abilities of self management, asks the subject which abilities they acquired in diverse areas of self-organization. Interpersonal abilities are the target of the second sub-scale which consists of 13 items; this set of questions asks the subjects to indicate the extent to which their experiences of sustainable leadership (in the secondary school) are affected by diverse abilities. The third sub-scale, called problem solving/decision making, includes four items. This section 
elicits information about problem resolution and decision making in secondary school. The fourth subscale examines the abilities of cognitive development and critical analysis. Seven items of this section centre on how the experiences of leadership affected cognitive development and critical analysis. The fifth sub-scale examines organization and planning and consists of 16 items. The sixth sub-scale deals with self-confidence. Five items examine self-confidence in social abilities and the ability to be assertive. Other items in this section examine the degree to which leadership experiences in the secondary education have helped clarify values and establish a personal code of ethics. Sensitivity for diversity is the focus of the seventh sub-scale. Four items ask participants about their sensitivity, respect and appreciation of others. The eighth sub-scale inquires about knowledge of technology. The two items of this section focus on the capacity to use software programs and search for diverse resources using the Internet.

Table 1. Domains of the abilities of leadership defined by Vann (2000)

\begin{tabular}{llcc}
\hline Dimensions & \multicolumn{1}{c}{ Description } & $\begin{array}{c}\text { Itens of } \\
\text { the Inventory }\end{array}$ & $\begin{array}{c}\text { Number of } \\
\text { itens }\end{array}$ \\
\hline Factor 1 & Self-management & $1-9$ & 9 \\
\hline Factor 2 & Interpersonal relations & $10-22$ & 13 \\
\hline Factor 3 & Problem solving/decision making & $23-26$ & 4 \\
\hline Factor 4 & Cognitive development/critical analysis & $27-33$ & 7 \\
\hline Factor 5 & Organization and planning & $34-49$ & 16 \\
\hline Factor 6 & Self-confidence & $50-54$ & 5 \\
\hline Factor 7 & Diversity & $55-58$ & 4 \\
\hline Factor 8 & Technology & $59-60$ & 2 \\
\hline
\end{tabular}

Three hypotheses were formulated for this study.

1. There are no significant differences in the sustainable abilities of leadership due to the gender of the participants.

2. There are no significant differences in the sustainable leadership abilities due to the age of the participants.

3. There are no significant differences in the sustainable abilities of leadership of the subjects due to the type of school attended (urban or rural).

The study participants included the senior students of two schools, one located in the urban area on the southern part of the island and the other in the rural area on the northern part of the island. These schools were chosen because of the contrasting areas where the schools area located. All senior students of the two schools during the academic year of 2008/2009 participated in this study. The school located in the rural area of the island was public, while the other, located in the urban area, was private. The questionnaires were applied within the classroom in June, 2009. SPSS (Statistical Package for the Social Sciences) version 16.0 was used to store and transform the data. Descriptive statistics were used to characterize the sample, analyse the trustworthiness of the questionnaire and apply the test t-Student to compare average scores between groups. The significance level of $95 \%$ was used to reject the null hypotheses. 


\section{Results}

158 students participated in this study: $46 \%$ (72) were male and 54\% (85) female. $71 \%$ (113) attended the private, urban school located in the capital of the island, a city of about one hundred and forty thousand people. The remaining subjects, 29\% (45) attended the public school located in the rural, northern part of the island, a county with about eight thousand people (Table 2). The students ranged between 17 and 26 years of age. Both the mean and the median average age were of 18 .

Table 2. Variables of the sample

\begin{tabular}{llcc}
\hline \multirow{2}{*}{ Variable } & \multirow{2}{*}{ Group } & $\mathbf{N}$ & Sample $(\mathbf{N}=\mathbf{1 5 8})$ \\
\cline { 3 - 4 } Sex & 1: Masculine & 72 & 45.6 \\
& 2: Feminine & 85 & 53.8 \\
& NR & 1 & 0.6 \\
\hline Age group & 1: 17-18 years & 121 & 76.6 \\
& 2: $\geq 19$ years & 35 & 22.2 \\
& NR & 2 & 1.2 \\
\hline Type of school & 1: Private & 113 & 71.5 \\
& 2: Public & 45 & 28.5 \\
\hline
\end{tabular}

In the 60 item questionnaire measuring sustainable leadership abilities, the answers varied between 1 (I completely disagree) and 4 (I completely agree), with lower scores indicating a lower level of leadership abilities. As depicted in Table 3, the levels of ability of the students are, by decreasing order of priority: 3.36 for the domain of technology, 3.27 for self-confidence, 3.18 for cognitive development, 3.16 for problem solving/decision making, 3.15 for self management, 3.14 for organization and planning, 3.13 for interpersonal relations and, 3.12 for cognitive development /critical analysis.

The internal consistency of factors is defined as the ratio of the variability in answers to questions measuring the same domain. That is, the answers differ not because the Inventory is confused but because the subjects have diverse opinions (Pestana \& Gageiro, 2005). Using the Alpha Cronbach ratio (*), the internal consistency of the eight domains of leadership ability was 0.809 , varying between 0.63 and 0.87 . The leadership abilities "Diversity" and "Problem solving/decisionmaking" have weak internal consistency, all the others have an internal consistency above .7 which are rated reasonable, good, very good (Table 3).

Testing the hypothesis $\mathrm{H}_{01}$, the test $t$ Student reveal no statistically significant difference between the genders (Table 4 ) and, therefore, the average for the 8 sustainable abilities of leadership are equal for both genders.

Testing the null hypotheses $\mathrm{H}_{02}$ and $\mathrm{H}_{03}$, we cannot reject these hypotheses ( $p$-value $>5 \%)$ and, therefore, we conclude that sustainable leadership abilities are independent of the age (Table 5) and the type of school (urban or rural) that the students attend (Table 6). 
Table 3. Measures of central tendency and dispersion for the domains of the leadership abilities

\begin{tabular}{lcccccc}
\hline Abilities of leadership & N & M & SD & Priority & Me & $\begin{array}{c}\text { Alpha- } \\
\text { Cronbach (*) }\end{array}$ \\
\hline 1. Self-management & 149 & 3.15 & 0.34 & 5 & 3.31 & $0.7^{2}$ \\
\hline 2. Interpersonal relations & 146 & 3.13 & 0.37 & 8 & 3.08 & $0.8^{3}$ \\
\hline $\begin{array}{l}\text { 3. Problem solving/decision } \\
\text { making }\end{array}$ & 155 & 3.16 & 0.45 & 4 & 3.25 & $0.6^{1}$ \\
$\begin{array}{l}\text { 4. Cognitive development/ } \\
\text { Critical analysis }\end{array}$ & 152 & 3.18 & 0.35 & 3 & 3.14 & $0.7^{2}$ \\
\hline 5. Organization and planning & 147 & 3.12 & 0.38 & 7 & 3 & $0.9^{4}$ \\
\hline 6. Self-confidence & 154 & 3.14 & 0.43 & 6 & 3 & $0.8^{3}$ \\
\hline 7. Diversity & 155 & 3.27 & 0.41 & 2 & 3.25 & $0.6^{1}$ \\
\hline 8. Technology & 156 & 3.36 & 0.61 & 1 & 3.5 & $0.7^{2}$ \\
\hline TOTAL & 158 & - & - & - & - & $0.809^{3}$ \\
\hline
\end{tabular}

(*) Legend: ${ }^{1}$ Weak internal consistency;

${ }^{2}$ Reasonable internal consistency;

${ }^{3}$ Good internal consistency;

${ }^{4}$ Very good internal consistency

Table 4. Results of the test $t$-Student for comparison of gender regarding leadership abilities

\begin{tabular}{|c|c|c|c|c|c|}
\hline Abilities of leadership & Sex & $\mathbf{N}$ & Average & SD & p-value \\
\hline \multirow[t]{2}{*}{ 1. Self management } & 1: Masculine & 66 & 3.16 & 0.37 & \multirow{2}{*}{0.797} \\
\hline & 2: Feminine & 83 & 3.15 & 0.33 & \\
\hline \multirow[t]{2}{*}{ 2. Interpersonal relations } & 1: Masculine & 68 & 3.12 & 0.42 & \multirow{2}{*}{0.652} \\
\hline & 2: Feminine & 78 & 3.15 & 0.33 & \\
\hline \multirow{2}{*}{$\begin{array}{l}\text { 3. Problem solving/decision } \\
\text { making }\end{array}$} & 1: Masculine & 70 & 3.16 & 0.51 & \multirow{2}{*}{0.951} \\
\hline & 2: Feminine & 85 & 3.16 & 0.40 & \\
\hline \multirow{2}{*}{$\begin{array}{l}\text { 4. Cognitive development/ } \\
\text { Critical analysis }\end{array}$} & 1: Masculine & 68 & 3.17 & 0.38 & \multirow{2}{*}{0.703} \\
\hline & 2: Feminine & 84 & 3.19 & 0.33 & \\
\hline \multirow{2}{*}{ 5. Organization and planning } & 1: Masculine & 65 & 3.11 & 0.43 & \multirow{2}{*}{0.785} \\
\hline & 2: Feminine & 82 & 3.13 & 0.35 & \\
\hline \multirow[t]{2}{*}{ 6. Self-confidence } & 1: Masculine & 69 & 3.20 & 0.41 & \multirow{2}{*}{0.119} \\
\hline & 2: Feminine & 85 & 3.10 & 0.45 & \\
\hline \multirow[t]{2}{*}{ 7. Diversity } & 1: Masculine & 70 & 3.25 & 0.44 & \multirow{2}{*}{0.595} \\
\hline & 2: Feminine & 85 & 3.29 & 0.38 & \\
\hline \multirow[t]{2}{*}{ 8. Technology } & 1: Masculine & 71 & 3.40 & 0.64 & \multirow{2}{*}{0.398} \\
\hline & 2: Feminine & 85 & 3.32 & 0.60 & \\
\hline
\end{tabular}


Table 5. Results of the test $t$-Student for comparison of the age groups regarding leadership abilities

\begin{tabular}{llcccc}
\hline \multicolumn{1}{c}{ Abilities of leadership } & Age groups & $\mathrm{N}$ & Average & SD & p-value \\
\hline 1. Self-management & $1: 17-18$ years & 119 & 3.13 & 0.33 & \multirow{2}{*}{0.334} \\
& $2: \geq 19$ years & 30 & 3.21 & 0.41 & \\
\hline 2. Interpersonal relations & $1: 17-18$ years & 115 & 3.14 & 0.36 & \multirow{2}{*}{0.892} \\
& $2: \geq 19$ years & 30 & 3.13 & 0.42 & \\
\hline 3. Problem solving/decision & $1: 17-18$ years & 119 & 3.17 & 0.43 & \multirow{2}{*}{0.837} \\
making & $2: \geq 19$ years & 35 & 3.16 & 0.45 & \\
\hline 4. Cognitive development/ & $1: 17-18$ years & 117 & 3.18 & 0.35 & \multirow{2}{*}{0.644} \\
critical analysis & $2: \geq 19$ years & 34 & 3.21 & 0.35 & \\
\hline 5. Organization and planning & $1: 17-18$ years & 115 & 3.11 & 0.80 & \multirow{2}{*}{0.231} \\
& $2: \geq 19$ years & 31 & 3.20 & 0.36 & \\
\hline 6. Self-confidence & $1: 17-18$ years & 120 & 3.11 & 0.43 & \multirow{2}{*}{0.197} \\
& $2: \geq 19$ years & 33 & 3.24 & 0.46 & \\
\hline 7. Diversity & $1: 17-18$ years & 120 & 3.26 & 0.40 & \multirow{2}{*}{0.300} \\
& $2: \geq 19$ years & 34 & 3.34 & 0.43 & \\
\hline 8. Technology & $1: 17-18$ years & 120 & 3.34 & 0.61 & \multirow{2}{*}{0.710} \\
& $2: \geq 19$ years & 35 & 3.39 & 0.63 & \\
\hline
\end{tabular}

Table 6. Results of the test $t$-Student for comparison of the type school relating to the leadership abilities

\begin{tabular}{|c|c|c|c|c|c|}
\hline Abilities of leadership & Type school & $\mathbf{N}$ & Average & DP & p-value \\
\hline \multirow[t]{2}{*}{ 1. Self-management } & 1: Private & 107 & 3.17 & 0.36 & \multirow{2}{*}{0.310} \\
\hline & 2: Public & 43 & 3.11 & 0.29 & \\
\hline \multirow[t]{2}{*}{ 2. Interpersonal relations } & 1: Private & 106 & 3.14 & 0.37 & \multirow{2}{*}{0.698} \\
\hline & 2: Public & 41 & 3.11 & 0.37 & \\
\hline \multirow{2}{*}{$\begin{array}{l}\text { 3. Problem solving/decision } \\
\text { making }\end{array}$} & 1: Private & 111 & 3.18 & 0.47 & \multirow{2}{*}{0.372} \\
\hline & 2: Public & 44 & 3.11 & 0.40 & \\
\hline \multirow{2}{*}{$\begin{array}{l}\text { 4. Cognitive development/ } \\
\text { critical analysis }\end{array}$} & 1: Private & 110 & 3.18 & 0.37 & \multirow{2}{*}{0.979} \\
\hline & 2: Public & 43 & 3.18 & 0.31 & \\
\hline \multirow[t]{2}{*}{ 5. Organization and planning } & 1: Private & 103 & 3.13 & 0.39 & \multirow{2}{*}{0.695} \\
\hline & 2: Public & 44 & 3.11 & 0.36 & \\
\hline \multirow[t]{2}{*}{ 6. Self-confidence } & 1: Private & 111 & 3.13 & 0.45 & \multirow{2}{*}{0.646} \\
\hline & 2: Public & 44 & 3.16 & 0.39 & \\
\hline \multirow[t]{2}{*}{ 7. Diversity } & 1: Private & 112 & 3.30 & 0.42 & \multirow{2}{*}{0.236} \\
\hline & 2: Public & 44 & 3.21 & 0.39 & \\
\hline \multirow[t]{2}{*}{ 8. Technology } & 1: Private & 113 & 3.36 & 0.65 & \multirow{2}{*}{0.823} \\
\hline & 2: Public & 44 & 3.34 & 0.50 & \\
\hline
\end{tabular}




\section{Discussion and conclusions}

The present study results from a research inquiry carried out in two secondary schools of Madeira Island: one private, located in the main urban area (southern part of the island); another public, located in the rural area (northern part of the island). The main goal of this study was to analyse the sustainable abilities of leadership of secondary education students and determine whether any differences existed related to gender, age, or location of school. Eight distinct domains were used to measure the sustainable leadership abilities: 1) self management; 2) interpersonal relations; 3) problem solving/ decision making; 4) cognitive development/critical analysis; 5) organization and planning; 6) self-confidence; 7) sensitivity for the diversity; 8) technology.

The ability domain that registered the highest average was "technology" (3.36). The ability least developed was "organization and planning" (3.12). However, about $5.2 \%$ of the subjects reported a low level of ability in this domain, with $92.9 \%$ registering levels that varied between moderate and high levels. $1.9 \%$ did not answer the items that constituted this domain.

Women presented higher levels of ability than men in the following domains: "interpersonal relations" ( $\mathrm{F}=3.15$ and $\mathrm{M}=3.12)$, "cognitive development/critical analysis" $(\mathrm{F}=3.19$ and $\mathrm{M}=3.17)$, "organization and planning" $(\mathrm{F}=3.13$ and $\mathrm{M}=3.11)$ and "diversity" ( $\mathrm{F}=3.29$ and $\mathrm{M}=3.25)$, although these differences are not statiscally significant in any domain. This study concluded that the sustainable leadership abilities of students are equal for both genders. These results are similar to those obtained by other authors (Bass, 1991; Posner \& Brodsky, 1994), though they contradict some studies which concluded that there is a difference between women and men on the "technologies" domain (Litchman, 1998; Bauer, 2000; Sax, Astin, Lindholm, Korn, Saenz, \& Mahoney, 2003; Foley, 2005a and 2005b; Al-Omari, Tineh, \& Khasawneh, 2008). On the other hand, several authors stress that men have more opportunities for becoming leaders while others suggest that sustainable leadership is a characteristic normally associated with males (Foley, 2005).

Taking the age into account, the students above 19 years of age reported higher levels of sustainable leadership in the following domains: "self management" (3.21 against 3.11), "cognitive development/decision making" (3.21 against 3.18), "organization and planning" (3.20 against 3.11), "self-confidence" (3.24 against 3.11), "diversity" (3.34 against 3.26) and "technology" (3.39 against 3.34). Again, however, none of these differences are statistically significant. Given that Kouzes and Posner $(1995,2009)$ suggest that leadership results from a set of observed practices which can be learned and improved, it is possible that, with age and experience, one might acquire higher levels of ability in these domains.

Finally, students who attend the urban school located in the capital of the island reported higher levels of competency in the following domains: "self-management" (3.17 against 3.11), "interpersonal relations" (3.14 against 3.11), "problem solving/ decision making” (3.18 against 3.11), "organization and planning” (3.13 against 3.11), "diversity" (3.30 against 3.21) and "technology". Despite these results, differences were not significant and identical results have been found by Foley (2005).

The results of this research affirm that both male and female students finish their secondary education studies with well developed and sustainable capabilities of leadership. In addition, the students attending the school in the rural area of Madeira 
Island acquire the same degree of leadership abilities as students in the urban area. This fact can indicate a successful result for the intervention programmes the local government has been conducting for the last twelve years, in particular the all day school programme in primary education (1st cycle) which was initiated in the rural areas. This hypothesis will be analysed in future research studies.

The authors recommend that similar studies be conducted in other countries at the secondary level in order to evaluate the capacity of secondary schools in developing students' sustainable abilities of leadership necessary to prepare them for studies on the tertiary level or to enter the highly competitive job market.

\section{References:}

Aksoy, H., \& Mittelhauser, M. (1998). Relationship between education and employment: How do employers use educational indicators in hiring? (Results from a participatory observation). Paper presented at World Council for Curriculum and Instruction Region VI. North American Chapter Interdisciplinary Education Conference: October 1-3, Ottawa, Canada.

Al-Omari, A., Tineh, A., \& Khasawneh, S. (2008). Leadership skills of first-year students at public universities in Jordan. Research in Post-Compulsory Education, 13(3), 251-266.

Attinasi, L. (1992). 1992 employer assessment of recent Pima Community College graduates. Tucson, AZ: Pima Community College.

Bass, B. (1991). Bass and Stogdill's handbook of leadership: A survey of theory and research. New York: Free Press.

Bauer, J. (2000). A technology gender divide: Perceived skill and frustration levels among female pre-service teachers. MSERA, Annual Conference Bowling Green, KY, November 15, 2000.

Foley, A. (2005a). Leadership skills of first-year students. Thesis submitted to the Faculty of Virginia Polytechnic Institute and State University, Master of Arts in education.

Foley, A. (2005b). The leadership corner: Creating a baseline for leadership education. Interchange, 34(2), 2-5.

Gale, S. (2002, October). Building leaders at all levels: Part 1 of 2. Workforce Management. Retrieved November 8, 2009, from http://findarticles.com/p/articles/mi m0 FXS/is 10 81/ai 93208691/pg 2/?tag=content;col1

Grogger, J., \& Eide, H. (1994). Changes in college skills and the rise in the wage college Premium. The Journal of Human Resources, 30, 280-310.

Hargreaves, A., \& Fink, D. (2007). Lideranēa sustentivel [Sustainable leadership]. Porto: Porto Editora.

Kerka, S. (1990). Job-related basic skills. ERIC Digest, 94, ED 318912. Retrieved November 8, 2009, from http://www.ericdigests.org/pre-9215/job.htm

Komives, S. (1991). Gender differences in the relationship of hall directors' transformational and transactional leadership and achieving styles. Journal of College Student Development, 32(2), 155-165.

Komives, S. (1994). Women student leaders: Self-perceptions of empowering leadership and achieving styles. NASPA Journal, 31(2), 102-111.

Kouzes, J., \& Posner, B. (1995). The leadership challenge: How to get extraordinary things done in organizations. San Francisco, CA: Jossey-Bass. 
Kouzes, J., \& Posner, B. (2009). O desafio da liderança [Leadership challenge]. Casal de Cambra: Caleidoscópio.

Linden, V., \& Fertman, C. (1998). Youth leadership: A guide to understanding leadership development in adolescents. San Francisco: Jossey-Bass.

Litchman, J. (1998). The cyber sisters club: Using the internet to bridge the technology gap within city girls. TH E Journal, 26(5), 47-54.

Pestana, M., \& Gageiro, J. (2005). Análise de dados para as ciências sociais: a complementariedade do SPSS, 4a edição revista e aumentada [Analysis of results for the social sciences: A complement for SPSS (4th ed.)]. Edições Sílabo: Lisboa.

Poom-Valickis, K., \& Elvisto, T. (2009). Students' motives and satisfaction with studies in the area of natural sciences and their willingness to continue studies in teacher education. Journal of Teacher Education for Sustainability, 11(2), 41-50.

Posner, B., \& Brodsky, B. (1994). Leadership practices of effective student leaders: Gender makes no difference. NASPA Journal, 31(2), 113-120.

Powell, G. (1989). Women and men in organizations. Newbury Park, CA: Sage.

Romano, C. (1996). A qualitative study of women student leaders. Journal of College Student Development, 37(6), 676-683.

Santosus, M. (2003). CIOS in a class by themselves. CIO Magazine. Retrieved November 8, 2009, from http://www.cio.com/article/31958/Leadership Training Courses Target_What_s_Different_About_IT_Execs.

Stronge (1998). Leadership skills in school and business. The School Administrator, 9(55), 21-26.

Sax, L., Astin, A., Lindholm, J., Korn, W., Saenz, V., \& Mahoney, K. (2003). The American freshman: National norms for fall 2003. Los Angeles: University of California.

Vann, M. (2000). Student leadership outcomes inventory. University Unions and Student Activities, Virginia Polytechnic Institute and State University, Blacksburg.

\section{Correspondence:}

Dr António V. Bento, Centre for Research in Education (CIE-UMa), University of Madeira, Campus da Penteada, 9000-390-Funchal-Portugal.Email: bento@uma.pt 